\title{
Circulating nucleic acids as biomarkers in breast cancer
}

\author{
Heidi Schwarzenbach*
}

\begin{abstract}
During tumor development, tumor cells release their nucleic acids into the blood circulation. This process occurs by apoptotic and necrotic cell deaths along with active cell secretion, resulting in high levels of circulating DNA, mRNA, and microRNA in the blood of patients with breast cancer. As circulating cell-free tumor nucleic acids may reflect the characteristics of the primary tumor and even of micrometastatic cells, they may be excellent blood biomarkers for screening breast cancer. Assays that allow the repetitive monitoring of patients by using blood samples as liquid biopsy may be efficient in assessing cancer progression in patients whose tumor tissue is not available. This review evaluates the recent data on the potential use of circulating cell-free nucleic acids as biomarkers for breast cancer.
\end{abstract}

\section{Introduction}

In 1948, cell-free nucleic acids (cfNAs) were observed in the human blood circulation for the first time [1]. In 1977, Leon and colleagues [2] reported that cell-free DNA (cfDNA) was present at concentrations ranging between 0 and $2 \mu \mathrm{g} / \mathrm{mL}$ in the serum of patients with breast cancer and that it was possible to analyze variations in the amount, depending on the stage of the disease and the response to the treatment received by the patients. In the late ' 80 s, correlations of the presence of cfDNA in the serum of tumor patients with the malignancy of their disease were described [3]. In 1994, the potential clinical relevance of cfNAs was documented by the detection of mutated Ras molecules in the blood from patients with pancreatic cancer and myelodysplastic syndrome $[4,5]$. These detections led to a wealth of studies that have analyzed genetic and epigenetic alterations,

*Correspondence: hschwarz@uke.uni-hamburg.de

Department of Tumor Biology, University Medical Center Hamburg-Eppendorf, Martinistraße 52, 20246 Hamburg, Germany such as microsatellite instability or loss of heterozygosity $(\mathrm{LOH})$ and aberrant methylation on cfDNA extracted from the plasma or serum of patients with cancer [6]. In 2000, it was shown that cell-free RNA (cfRNA), namely telomerase mRNA, can also be detected in the serum of patients with breast cancer [7]. Not until 2009 could tumor-specific changes be demonstrated in the levels of circulating microRNAs (miRs) in the serum of patients with breast cancer [8].

The release of cfNAs into the bloodstream occurs by different sources, including the primary tumor, tumor cells that circulate in the blood, micrometastatic deposits that are present at distant sites (for example, bone marrow and liver), and normal cell types, such as hematopoietic and stromal cells [9]. The physiological events that lead to the increase of cfNAs in the blood during cancer development and progression comprise increased apoptotic and necrotic cell deaths as well as active secretion into the blood circulation $[10,11]$. Thus, both tumor and normal cfNAs circulate in the blood of patients with tumors. The proportion of tumor cfNAs varies owing to the size of the tumor or metastases. It has been estimated that, for a patient with a tumor that weighs $100 \mathrm{~g}$, which corresponds to $3 \times 10^{10}$ tumor cells, up to $3.3 \%$ of tumor DNA may enter the blood every day [12]. Besides, the DNA fragmentation seems to be different in various cancer entities. Whereas DNA integrity was increased in patients with breast cancer, indicating predominantly necrotic origin, the levels of short, presumably apoptotic DNA fragments were higher in patients with other cancer types [6]. Alternatively, DNases can contribute to these shorter fragments by digesting high-molecular weight DNA. The clearance of cfNAs occurs by degradation and other physiological filtering events of the blood and lymphatic circulation. Usually, cfNAs are removed from the blood by the liver and kidney, and their half-life in the circulation is variable, ranging from 15 minutes to several hours $[13,14]$.

\section{Plasma/serum cfDNA levels and integrity}

Tumor development is frequently accompanied by increased levels of cfDNA in the peripheral blood. A wide 
range (from 100 to $550 \mathrm{ng}$ ) of cfDNA per milliliter of blood has been detected in patients with breast cancer [15]. On average, the size of cfDNA varies between small fragments of 70 to 200 base pairs and large fragments of approximately 21 kilobases [10]. The extraction of cfDNA from serum or plasma has been carried out by standard commercially available DNA kits. Different fluorescencebased methods (PicoGreen (Invitrogen) staining and ultraviolet (UV) spectrometry) or quantitative polymerase chain reaction (PCR) (SYBR Green and TaqMan (Applied Biosystems)) have been used to quantify the concentrations of cfDNA [16].

In patients with breast cancer, discrepant data on the levels of cfDNA have been reported by using serum or plasma (Additional File 1). Although the serum levels of cfDNA could differentiate between healthy women and patients with invasive breast cancer, they could not discriminate malignant from benign breast lesions [17]. In contrast, the plasma concentrations of cfDNA were significantly higher in patients with breast cancer than those in the patients with benign tumors $[18,19]$. These analyses were carried out by using serum or plasma from different patient populations. Usually, the DNA concentrations in serum are higher than those in plasma because DNA may also be released from hematopoietic cells during the clotting process. Whether plasma actually reflects cfDNA amounts in the blood of patients with breast cancer more appropriately than serum needs to be verified in the same patient population. In general, the data on the quantification of cfDNA do not seem to be useful in diagnostic settings of patients with breast cancer, because of the overlapping cfDNA concentrations that are found among patients with benign and malignant disease. However, levels of cfDNA showed a greater dynamic range and correlation with changes of tumor burden than did the cancer antigen CA 15-3 or circulating tumor cells (CTCs) and were suggested as an informative, inherently specific, and highly sensitive biomarker of metastatic breast cancer [20]. Therefore, quantification of cfDNA could be useful in combination with other blood tumor biomarkers. This notion is supported by the reported prognostic relevance of cfDNA yields in patients with breast cancer. Within this patient cohort, increased serum DNA levels were associated with poorer overall and disease-free survival [17].

Apart from the primary tumor, CTCs and disseminated tumor cells (DTCs) also seem to have an impact on the levels of cfDNA in the blood of patients with breast cancer [21]. It has been reported that cfDNA is able to indicate the CTC status [22]. The use of CTCs and DTCs as prognostic markers has been well documented. Enrichment and detection methods of these tumor cells in blood and bone marrow include the CellSearch system
(Janssen Diagnostics, Raritan, NJ, USA), positive or negative immuno-selection or both, and molecular approaches [23]. With these methods, a correlation between the presence of CTCs and cfDNA amounts in the blood of patients with breast cancer was demonstrated [22]. During the dormancy phase of breast cancer (the time between removal of the primary tumor and subsequent relapse of a patient who has been clinically disease-free [24]), an inverse relationship between cell viability in the bone marrow (the presence of DTCs) and cell death in the plasma (the levels of cfDNA) was observed [25].

In addition, the measurements of the integrity of cfDNA by quantifying short and long DNA fragments of non-coding ALU repeat sequences, which are interspersed on all chromosomes throughout the genome, led to promising results. These analyses demonstrated that an ALU DNA integrity assay may be sensitive to detect early-stage metastasis to regional tumor-draining lymph nodes [26]. A PCR assay also showed that longer DNA fragments released from non-apoptotic cells mainly contribute to the rise in DNA levels during adjuvant systemic therapy [27]. Thus, further investigations are necessary to address the specificity of such an assay as a blood biomarker for breast cancer.

\section{Genetically altered plasma/serum cfDNA}

Numerous tumor-associated chromosomal regions, which are involved in breast cancer and have an influence on cell cycle, cell adhesion, or apoptosis, have been identified by cytogenetic and molecular genetic methods. Allelic imbalances, such as LOH and microsatellite instability, are usually assessed by using PCR-based fluorescence microsatellite analysis (Additional File 1). However, accurate identification of LOH on cfDNA is often restricted by technical limitations such as poor quality and quantity of tumor-specific DNA. In PCR, the use of DNA fragments from blood can result in false-positive data and artificial LOHs displaying either DNA loss at the shorter or longer allele of the same locus and in the same plasma sample. The low incidence of LOH detected on cfDNA has been explained in part by the dilution of tumor-associated cfDNA in the blood by DNA released from leukocytes and stroma cells [28]. Also, the abnormal proliferation of benign cells, due to inflammation or tissue repair processes, leads to the accumulation of DNA in the blood and the masking of $\mathrm{LOH}$ [29]. The proportion of wildtype DNA in the blood circulation of patients with breast cancer is unknown and may fluctuate. Therefore, only a fraction of cfDNA is diagnostically relevant. The major problem of an approach on cfDNA has been assay specificity and sensitivity. Nevertheless, the fact that small tumors of histoprognostic grade 1 or in situ carcinomas can present DNA alterations in the plasma or 
serum at an early stage suggests that analyses of cfDNA may be developed into a useful diagnostic tool for breast cancer [30]. This is also supported by the significant associations of $\mathrm{LOH}$ with some risk factors of patients with breast cancer and the demonstrated possibility of monitoring cfDNA in patients undergoing systemic therapy [28,31]. In this regard, it was reported that after mastectomy the persistence of plasma tumor DNA was associated with prognostic, histological parameters that point to potentially undetectable micrometastatic disease [32]. Moreover, the prognostic value of $\mathrm{LOH}$ frequency on cfDNA to predict disease-free survival of patients with breast cancer has been revealed [33]. DNA loss of the chromosomal region 13q31-33 may be an indication of lymphatic tumor cell spread [17]. Deletions of the loci 3p24.2-25 and 9p21 were significantly associated with tumor relapse [31]. However, owing to the high background of normal cfDNA in the blood, the $\mathrm{LOH}$ frequency detected in these studies is usually low. Therefore, alternative approaches, such as improved cfDNA extraction methods for detection of tumorspecific deletions, are needed. My laboratory tried to improve the detection rate of $\mathrm{LOH}$ by fractionating the extracted plasma DNA in low- and high-molecular weight DNA by using two different column systems. We detected a higher $\mathrm{LOH}$ frequency in the fraction containing short DNA fragments than in the fraction containing long DNA molecules and obtained important information on DNA losses of tumor suppressor genes, such as TIG1, PTEN, cyclin D2, RB1, and BRCA1. In particular, loss of the cyclin D2 gene seems to be a prognostic marker for patients with breast cancer [34].

Besides LOH, mutations on cfDNA have been detected in the blood of patients with breast cancer. Mutations on cfDNA are usually probed by using allele-specific PCR assays, but nowadays, deep and next-generation pairedend sequencing [35] of entire genes is also applied. Noninvasive, exome-wide analysis of cfDNA could complement current invasive biopsy approaches to identify specific mutations associated with acquired drug resistance (for example, against tamoxifen, trastuzumab, or lapatinib) in advanced cancers [36]. The detection of p53 mutations on plasma cfDNA may be used as an early prognostic factor to indicate recurrence or distant metastasis of patients with breast cancer [37]. Moreover, cfDNA analyses, which showed the presence of amplified circulating human epidermal growth factor receptor 2 (HER2) in the plasma, could provide a marker for patients with HER2-positive breast cancer [38]. In $40 \%$ of breast cancers, somatic mutations of PIK3CA (a class I phosphatidylinositol-3 kinase (PI3K) catalytic subunit), which modulate PI3K signaling transduction, are present. Clinical trials begin to apply and evaluate inhibitors of PI3K signaling pathways. In patients with metastatic breast cancer, the feasibility and potential utility of cfDNA for detection of PIK3CA mutations were reported [39]. The major problem of this approach was in its assay specificity and sensitivity. A requirement for assays targeting cfDNA mutations is that the mutation in the tumor occurs frequently at a specific genomic site. A major drawback of cfDNA assays is the low frequency of some mutations that occur in tumors and the interference by wild-type sequences.

In paired tumor tissue and plasma samples, high-level DNA amplifications with specific copy number variations were identified in clusters at several chromosome arms. Up to 12 years after diagnosis, these amplifications were still detectable in the follow-up plasma samples of patients. The cfDNA array analysis could distinguish between preoperative cancer patients and those who have had surgery and treatment [40]. Surprisingly, Bechmann and colleagues [41] found that neither the levels of cfDNA nor those of HER2 gene copy number are elevated in patients with primary breast cancer. During neoadjuvant chemotherapy, the levels of both parameters increased but without any relation to treatment effect [41].

\section{Epigenetically altered plasma/serum cfDNA}

DNA methylation is a common early event in carcinogenesis and can be a potential predictor of cancer risk. Epigenetic alteration may lead to inactivation of tumor suppressor genes by methylation of $\mathrm{CpG}$-rich regions near the transcriptional start site. Assays for the detection of tumor-specific changes in DNA methylation have a higher sensitivity than microsatellite analyses and mutation analyses and represent most promising approaches for risk assessment in patients with breast cancer (Additional File 1). Aberrantly methylated cytosines within $\mathrm{CpG}$ dinucleotides can be detected by sodium bisulphite treatment of extracted cfDNA, which converts only unmethylated cytosines to uracil. The modified cfDNA is then analyzed by using either methylation-specific PCR (MSP) with primer sets that specifically bind to methylated and unmethylated DNA or DNA sequencing. Another method for determination of the DNA methylation status is a PCR using extracted cfDNA enzymatically treated with methylation-sensitive restriction enzymes which cleave unmethylated DNA but not methylated DNA [42].

Although epigenetic alterations are not unique for breast cancer, there are tumor suppressor genes that are frequently methylated and downregulated in breast cancer $[43,44]$. In particular, methylation of circulating tumor suppressor genes, which were not methylated in serum or plasma of healthy women, has been described in patients with breast cancer. This methylation of cfDNA that resembles the DNA methylation pattern of 
the primary tumor may be a highly specific diagnostic biomarker and underscores the utility of cfDNA as a non-invasive tool for methylation analysis. A phenotypic feature of breast tumor biology is the methylated cfDNA of RASSF1A (ras association domain family protein $1 \mathrm{~A}$ ), $M A L$ (myelin and lymphocyte protein), and SFRP1 (secreted frizzled-related protein 1) [43]. The epigenetic inactivation of RASSF1A is one of most common molecular changes in cancer, suggesting RASSF1A methylation as an attractive biomarker for early cancer detection $[45,46]$. Its aberrant promoter hypermethylation may be common among high-risk women and detectable years before breast cancer diagnosis [47]. In the plasma of patients with breast cancer, the CST6 promoter is also highly methylated and its gene product cystatin is an endogenous inhibitor of lysosomal cysteine proteases and functions to protect cells against uncontrolled proteolysis, but not in healthy individuals $[48,49]$. However, methylation assays of a single gene frequently result in a low sensitivity (of less than $30 \%$ ); therefore, analyses of several genes have been accomplished, resulting in a more reasonable sensitivity with high specificity in breast cancer detection [50]. With eight selected tumor suppressor genes used as a panel, a sensitivity and specificity of more than $90 \%$ could be achieved in distinguishing between breast cancer and normal samples. The selected genes were involved in cell cycle, DNA repair, invasion, metastasis, signal transduction, and cell detoxification [51]. Moreover, the combination of an MSP assay of GSTP1 (glutathione Stransferase P1), RASSF1A, and RAR 32 (retinoic acid receptor $\beta 2$ ) with the quantification of CEA or CA15-3 (or both) is promising for enhancing the sensitivity to diagnose metastatic breast cancer [52]. Finally, the combination of an MSP assay of RAR $\beta 2$ and RASSF1A with the quantitative analysis of cfDNA distribution between cell-bound and cell-free blood fractions provides a sensitive assay for discriminating malignant from benign breast tumors [53]. Another study pointed out that hypermethyled BRCA1, p16, and 14-3-3sigma detected in all histological types, stages, and grades in the serum may enhance early detection of sporadic breast cancer [44]. The correlation of methylated $A P C$ (adenomatous polyposis coli), RASSF1A, and ER1 (estrogen receptor 1) with the presence of CTCs was related to a phenotypic feature of more aggressive breast tumor biology [22]. In this regard, the association of methylated APC and GSTP1 molecules with CTCs also correlated with a more aggressive breast tumor phenotype and an advanced disease stage [54]. A relationship between the presence of CTCs and highly methylated cfDNA of $S O X 17$ (sex determining region Ybox 17) promoter was detected in patients after surgical removal of the primary tumor [55].
Besides the diagnostic value of methylated cfDNA, changes in the methylation pattern can have a prognostic value. Patients with breast cancer showing concurrently methylated $E R \beta$ (estrogen receptor $\beta$ ) and $R A R \beta 2$ had a significantly shorter median overall survival, underlining that hypermethylation of these two genes may serve as an adverse prognostic factor for breast cancer [56]. In pretreatment serum, methylated RASSF $1 A$ and APC may be independently associated with poor outcome and more powerful predictors than standard prognostic parameters [57]. Methylated GSTP1, RASSF1A, and RAR $\beta 2$ constitute a significant and independent prognostic factor, and their combination with total serum cfDNA seems to be even more effective for the prognosis of patients with breast cancer [58]. The prognostic significance of methylated RASSF1A was also described in the plasma of the patients [59].

Methylation patterns of cfDNA may also be used to monitor treatment. After surgery, tamoxifen treatment or combined treatment of patients with breast cancer, the methylation pattern of cfDNA may change and become similar to that of healthy controls [60]. It was reported that demethylation of RASSF1A throughout the treatment with tamoxifen indicates a response but that its persistence or new appearance in the serum means resistance to adjuvant tamoxifen therapy [61]. Even early during neoadjuvant therapy, methylated RASSF1 in the serum became undetectable in patients with complete pathological response, whereas methylated RASSF1 persisted longer or throughout the treatment in patients who had only partial or minimal pathological response [62].

\section{Circulating plasma/serum nucleosomes}

CfDNA circulates in the human blood in diverse forms: as naked (unbound) DNA, DNA associated with histones (mononucleosomes and oligonucleosomes), DNA bound to plasma proteins or packed in apoptotic bodies. Circulating nucleosomes are usually quantified by enzymelinked immunosorbent assays (ELISAs). Independent of the histological cancer type, elevated levels of circulating nucleosomes have been observed in the blood [63]. For breast tumors, this increase seems not to be cancerspecific, as they cannot discriminate between benign and malignant breast lesions [64]. However, circulating nucleosomes can be used as a sensitive marker for apoptotic cell death, based on the correlation of their concentrations with the activities of serum caspases-3 and -7 , which are involved in the apoptotic pathway. My laboratory found that increased serum levels of nucleosomes, along with the changes in apoptosis-related deregulation of proteolytic activities, may be linked to breast cancer progression [64]. In breast cancer patients after mastectomy, the levels of circulating nucleosomes 
decreased and recurrence led to an increase in the levels. Substantially, their quantification may be predictive of leukopenia [65].

To sum up the literature (Additional File 1), circulating nucleosomes do not appear to be suitable for cancer diagnosis, because of their non-specific elevations. Conversely, circulating nucleosomes are most valuable for monitoring cytotoxic cancer therapy, particularly for the early estimation of therapy efficacy. Combinations with other oncological or apoptotic biomarkers have been suggested to improve the sensitivity of detecting non-response to cytotoxic chemotherapy [66]. The specificity of circulating nucleosomes for cancer diseases may be increased by the combination with histone modifications. Histone modifications of the nucleosomes were also quantified in the serum of patients with breast cancer, and the respective measurements showed that the levels of trimethylated lysine of histone 3 (H3K9me3) and histone 4 (H4K20me3) were elevated [67].

\section{Plasma/serum cfRNA}

Besides cfDNA, circulating gene transcripts are detectable in the serum and plasma of patients with breast cancer. This RNA is packaged into microparticles, such as exosomes, microvesicles, or multivesicles, which are shed from cellular surfaces into the bloodstream [68,69]. By its packaging, RNA is relatively stable in the blood and protected from degradation by circulating RNases. The detection and identification of cfRNA can be performed by using microarray technologies or reverse transcription-quantitative real-time PCR [70]. In this respect, it was reported that plasma mammaglobin mRNA alone or in combination with CA15-3 may be used as a valuable non-invasive approach for the diagnosis and detection of metastasized breast cancer [71]. Furthermore, levels of CCND1 mRNA, which encodes the cell-cycle protein cyclin D1, identified patients with breast cancer with poor overall survival in good-prognosis groups and patients who were non-responsive to tamoxifen [72].

As already demonstrated for cfDNA, the quantification of the concentrations of cfRNA might be used as a biomarker (Additional File 1) if combined with other tumor markers. However, the release of RNA and DNA into the blood circulation is not restricted to a specific disease condition but rather seems to be a non-specific reaction when cells, organs, or whole organisms are put under stress [73]. Consequently, the determination of breast cancer-specific RNA transcripts could advance this assay as a diagnostic tool.

\section{Circulating plasma/serum microRNAs}

In particular, circulating miRs have recently attracted a great deal of attention as promising non-invasive biomarkers for breast cancer (Additional File 1). As RNA molecules, miRs are incorporated in microvesicles or bound to proteins and therefore are highly stable in the blood [74]. MiRs are a class of naturally occurring small non-coding RNA molecules and are involved in a wide variety of cellular processes. Thereby, they modulate posttranscriptionally the expression of more than half of protein-coding genes in mammalian genomes. They repress the translation or regulate degradation of their target mRNA by sequence-specific binding. Mature miRs consist of 19 to 25 nucleotides and are derived from hairpin precursor molecules of 70 to 100 nucleotides. As half of human miRs are localized in cancer-associated and fragile chromosomal regions, which may exhibit DNA amplifications, deletions, or translocations during tumor development, their expression is frequently deregulated in breast cancer [75]. Currently, expression microarrays that cover more than 1,000 mature human miR sequences listed in the miR database (miRBase) or the new technology next-generation sequencing (NGS) allow the screening of deregulated transcript levels of circulating miRs. Subsequently, the aberrant expression levels of the miRs deduced from the array or NGS data can be examined by quantitative real-time PCR in single assays.

Circulating populations of miRs are, in part, tumorderived [76], and their altered expression levels are associated with clinicopathologic features of breast cancer. This opens up the possibility of using them as noninvasive diagnostic biomarkers of breast cancer. Different combinations of circulating miR-145, miR-155, miR-382, miR-451, miR-148b, miR-409-3p, and miR-801 have been reported to be valuable biomarkers for distinguishing breast cancer from normal controls [77-80]. In addition, the levels of circulating miR-202 may be eligible for detection of early-stage breast cancer [81]. Circulating miR-10b has been suggested to be a useful biomarker for the identification of lymph node and bone metastatic breast cancer $[82,83]$ and appears to be a promising target for the development of new anti-metastasis agents. Systemic treatment of tumor-bearing mice with a chemically modified anti-miR-10b oligonucleotide suppressed formation of lung metastases but did not reduce primary mammary tumor growth [84]. Also, the levels of circulating miR-215, miR-299-5p, and miR-41 were deregulated in patients with metastatic breast cancer and could become valuable markers for detection of metastases [85].

MiR-21 is one of the most frequently investigated miRs in cancer and was suggested as a potential broadspectrum serum-based biomarker for the detection of solid cancers [86]. Investigations in the breast cancer cell line MCF-7 showed that miR-21 is responsible for migration and invasion by activation of the epithelialmesenchymal transition (EMT). In this process, miR-21 activates mesenchymal cell markers ( $\mathrm{N}$-cadherin and 
Vimentin) and inhibits the epithelial cell marker Ecadherin [87]. Real-time quantitative PCR that was applied directly in a serum assay showed that high circulating miR-21 concentrations correlated significantly with visceral metastasis [88]. However, discrepant data associating the relationship of serum miR-21 with tumor size and a positive lymph node status have also been reported $[86,89]$.

As an indicator of metastatic spread to regional lymph nodes, circulating miR-214, which targets the tumor suppressor gene phosphatase and tensin homolog $(P T E N)$, was described in breast cancer [90]. Higher serum levels of miR-34a were observed in patients with advanced-stage disease than in patients at early tumor stages, and changes in levels of miR-10b, miR-34a, and miR-155 correlated with the presence of metastases [91]. Circulating miR-155, which mediates transforming growth factor-beta (TGF- $\beta$ )-induced EMT and cell invasion [92], was differentially expressed in the serum of women with hormone-sensitive breast cancer compared with women with hormone-insensitive breast cancer [8] and correlated with clinical stage, p53 status, and the proliferation marker Ki-67 [93]. Finally, an association of circulating miRs and CTCs was detected. Patients with CTC-positive metastatic breast cancer had significantly higher levels of miR-141, miR-200a, miR-200b, miR-200c, miR-203, miR-210, miR-375, and miR-801 in their plasma than CTC-negative patients and healthy women. In particular, miR-200b was found to be a promising prognostic marker for progression-free and overall survival [94].

Besides the diagnostic and prognostic values, changes in miR levels play a role in the treatment of patients with breast cancer. Serum and in vitro measurements showed that miR-125b, which is downregulated in HER2-amplified and -overexpressing breast cancers [95], may predict chemoresistance in the patients. Increased resistance to anti-cancer drug administration was observed in breast cancer cells with ectopically expressed miR-125b. Conversely, when the level of miR-125b abated, breast cancer cells became sensitized to chemotherapy [96]. Because treatment with the anti-HER2 monoclonal antibody trastuzumab has significantly improved the survival of patients with HER2-positive breast carcinomas, trastuzumab belongs to the standard treatment for these patients. However, not all patients respond to the treatment of trastuzumab. Therefore, the quantification of circulating miR-210 could additionally be beneficial because plasma miR-210, which was associated with trastuzumab sensitivity, may predict and monitor response to therapies with trastuzumab [97]. Additionally, miR-210 seems to be a marker for hypoxia levels in tumors and is induced in hypoxic cancer cells [98]. Tumor hypoxia has been associated with a poor prognosis and resistance to chemotherapy and radiation therapy [99]. These data demonstrate miR-210 as a therapeutic indicator for breast cancer.

In contrast to the reported positive findings, a comprehensive review of genome-wide circulating miR data found that a concordance between the data was almost completely lacking and that, consequently, the utility of quantification of circulating miRs for breast cancer detection is still questionable [100]. These discrepancies might be due mainly to the lack of a standardized method and an established endogenous miR control to normalize miR amounts.

\section{CfDNA in other body fluids}

Besides plasma or serum, ductal fluid and urine have been used for the study of cfDNA. For LOH analyses, ductal lavage fluid was used from $B R C A 1$ gene mutation carriers, who are at increased risk for developing breast cancer. Although sufficient amounts of cfDNA could be extracted from ductal fluid for PCR amplification, further studies are required to evaluate the specificity and predictive value of $\mathrm{LOH}$ on cfDNA in this fluid for breast cancer development [101]. Moreover, MSP analyses of cfDNA, extracted from blood and urine of patients with breast cancer, revealed that the presence of methylated promoters of RASSF1A and RAR $\beta 2$ genes in the plasma was accompanied by detection of those methylated markers in the urine [102]. This finding suggests that cfDNA isolated from urine may be applied in breast cancer diagnostics. However, given the few publications that have analyzed cfNAs in these body fluids, more studies are needed to demonstrate the utility of ductal fluid and urine as liquid biopsies.

\section{Conclusions and perspectives}

Genetic and epigenetic analyses of the primary tumor are invasive and confounded by intratumor heterogeneity. To circumvent the need for tissue biopsies, blood plasma and serum as liquid biopsies are ideal sources for extraction and repeated monitoring studies of levels of cfNAs. Profiling of cfNAs may improve cancer diagnosis, predict outcome for patients with breast cancer, and be a therapeutic target in these patients. In regard to their rapid changes in levels after onset of therapy, changes in cfNA levels could be an early response marker. Detection of resistance-conferring genetic and epigenetic alterations of cfDNA could facilitate personalized treatment of patients with breast cancer. Therefore, analyses of cfDNA could monitor a specific response to therapy and indicate whether a treatment is redundant or another treatment method is warranted.

For a few years, there has been great interest in the development of circulating miRs as blood-based biomarkers for the screening of breast cancer. The ability to 
identify a panel of miRs as a biomarker rather than relying on one marker will increase the odds of successful treatment in a heterogeneous population of patients. In addition, these studies could determine whether miRs can be direct targets for future therapeutic interventions. However, an important question that needs to be addressed for a miR-based therapy is that a single miR can target numerous mRNAs. Since the gene products of the targeted mRNAs are involved in several signal transduction pathways, the impact of each miR on different signaling pathways needs to be identified before applying miRs as targeted therapy.

To date, development of a reliable, reproducible, and non-invasive clinical test using cfNAs is still in its infancy. One of the major challenges of the use of cfNAs as biomarkers in clinical practice is their sensitivity and specificity, particularly given the poorly characterized analytical variables. Therefore, extensive research is needed to standardize various technical issues prior to the routine clinical use of cfNAs as biomarkers. In this respect, the use of starting material (serum or plasma) in the extraction protocols, the point of time (before and after surgery or therapy), and treatments (chemotherapy and endocrine therapy) should be considered. In case of miRs, the selection of an endogenous reference gene to normalize the relative data of the quantitative real-time PCR is a further confounding factor. Given these issues, a well-controlled analysis of cfNAs should be carried out in a large cohort of patients with breast cancer and healthy volunteers. These studies will then provide evidence of whether cfNAs may be useful as blood-based biomarkers in clinical practice.

\section{Additional File}

Additional File 1. Detection of circulating nucleic acids and its alterations in plasma and serum of patients with breast cancer.

\section{Abbreviations \\ APC, adenomatous polyposis coli; cfDNA, cell-free DNA; cfNA, cell-free nucleic acid; cfRNA, cell-free RNA; CTC, circulating tumor cell; DTC, disseminated tumor cell; ELISA, enzyme-linked immunosorbent assay; EMT, epithelial-mesenchymal transition; ER, estrogen receptor; GSTP1, glutathione S-transferase P1; HER2, human epidermal growth factor receptor; $\mathrm{LOH}$, loss of heterozygosity; MAL, myelin and lymphocyte protein; miR, microRNA; MSP, methylation-specific polymerase chain reaction; NGS, next- generation sequencing; PCR, polymerase chain reaction; PIK3CA, a class I phosphatidylinositol-3 kinase (PI3K) catalytic subunit; PTEN, phosphatase and tensin homolog; RAR 32 , retinoic acid receptor $\beta 2$; RASSF1A, ras association domain family protein 1A; SFRP1, secreted frizzled-related protein 1.}

\section{Competing interests}

The author declares that she has no competing interests.

Published: 23 September 2013

\section{References}

1. Mandel P, Métais P: [Nucleic acids in human blood plasma]. C R Acad Sci Paris 1948, 142:241-243. Article in French.
2. Leon SA, Shapiro B, Sklaroff DM, Yaros MJ: Free DNA in the serum of cancer patients and the effect of therapy. Cancer Res 1977, 37:646-650.

3. Stroun M, Anker P, Maurice P, Lyautey J, Lederrey C, Beljanski M: Neoplastic characteristics of the DNA found in the plasma of cancer patients. Oncology 1989, 46:318-322.

4. Sorenson GD, Pribish DM, Valone FH, Memoli VA, Bzik DJ, Yao SL: Soluble normal and mutated DNA sequences from single-copy genes in human blood. Cancer Epidemiol Biomarkers Prev 1994, 3:67-71.

5. Vasioukhin V, Anker P, Maurice P, Lyautey J, Lederrey C, Stroun M: Point mutations of the $\mathrm{N}$-ras gene in the blood plasma DNA of patients with myelodysplastic syndrome or acute myelogenous leukaemia. $\mathrm{Br} J$ Haematol 1994, 86:774-779.

6. Schwarzenbach $\mathrm{H}, \mathrm{Hoon}$ DS, Pantel $\mathrm{K}$ : Cell-free nucleic acids as biomarkers in cancer patients. Nat Rev Cancer 2011, 11:426-437

7. Chen XQ, Bonnefoi H, Pelte MF, Lyautey J, Lederrey C, Movarekhi S, Schaeffer P, Mulcahy HE, Meyer P, Stroun M, Anker P: Telomerase RNA as a detection marker in the serum of breast cancer patients. Clin Cancer Res 2000, 6:3823-3826.

8. Zhu W, Qin W, Atasoy U, Sauter ER: Circulating microRNAs in breast cancer and healthy subjects. BMC Res Notes 2009, 2:89.

9. Schwarzenbach H, Alix-Panabieres C, Muller I, Letang N, Vendrell JP, Rebillard $X$, Pantel K: Cell-free tumor DNA in blood plasma as a marker for circulating tumor cells in prostate cancer. Clin Cancer Res 2009, 15:1032-1038.

10. Jahr S, Hentze H, Englisch S, Hardt D, Fackelmayer FO, Hesch RD, Knippers R: DNA fragments in the blood plasma of cancer patients: quantitations and evidence for their origin from apoptotic and necrotic cells. Cancer Res 2001, 61:1659-1665.

11. Stroun M, Lyautey J, Lederrey C, Olson-Sand A, Anker P: About the possible origin and mechanism of circulating DNA apoptosis and active DNA release. Clin Chim Acta 2001, 313:139-142.

12. Diehl F, Li M, Dressman D, He Y, Shen D, Szabo S, Diaz LA Jr., Goodman SN, David KA, Juhl H, Kinzler KW, Vogelstein B: Detection and quantification of mutations in the plasma of patients with colorectal tumors. Proc Nat/ Acad SciUSA 2005, 102:16368-16373.

13. Botezatu I, Serdyuk O, Potapova G, Shelepov V, Alechina R, Molyaka Y, Ananév V, Bazin I, Garin A, Narimanov M, Knysh V, Melkonyan H, Umansky S, Lichtenstein A: Genetic analysis of DNA excreted in urine: a new approach for detecting specific genomic DNA sequences from cells dying in an organism. Clin Chem 2000, 46 (8 Pt 1):1078-1084.

14. Minchin RF, Carpenter D, Orr RJ: Polyinosinic acid and polycationic liposomes attenuate the hepatic clearance of circulating plasmid DNA. J Pharmacol Exp Ther 2001, 296:1006-1012.

15. Fleischhacker M, Schmidt B: Circulating nucleic acids (CNAs) and cancer a survey. Biochim Biophys Acta 2007, 1775:181-232.

16. Pinzani P, Salvianti F, Pazzagli M, Orlando C: Circulating nucleic acids in cancer and pregnancy. Methods 2010, 50:302-307.

17. Schwarzenbach H, Muller V, Milde-Langosch K, Steinbach B, Pantel K: Evaluation of cell-free tumour DNA and RNA in patients with breast cancer and benign breast disease. Mol Biosyst 2011, 7:2848-2854.

18. Huang ZH, Li LH, Hua D: Quantitative analysis of plasma circulating DNA at diagnosis and during follow-up of breast cancer patients. Cancer Lett 2006, 243:64-70.

19. Kohler C, Radpour R, Barekati Z, Asadollahi R, Bitzer J, Wight E, Burki N, Diesch C, Holzgreve W, Zhong XY: Levels of plasma circulating cell free nuclear and mitochondrial DNA as potential biomarkers for breast tumors. Mol Cancer 2009, 8:105.

20. Dawson SJ, Tsui DW, Murtaza M, Biggs H, Rueda OM, Chin SF, Dunning MJ, Gale D, Forshew T, Mahler-Araujo B, Rajan S, Humphray S, Becq J, Halsall D, Wallis M, Bentley D, Caldas C, Rosenfeld N: Analysis of circulating tumor DNA to monitor metastatic breast cancer. N Engl J Med 2013, 368:1199-1209.

21. Alix-Panabieres $\mathrm{C}$, Schwarzenbach $\mathrm{H}$, Pantel K: Circulating tumor cells and circulating tumor DNA. Annu Rev Med 2011, 63:199-215.

22. Van der Auwera I, Elst HJ, Van Laere SJ, Maes H, Huget P, van Dam P, Van Marck $E A$, Vermeulen PB, Dirix LY: The presence of circulating total DNA and methylated genes is associated with circulating tumour cells in blood from breast cancer patients. Br J Cancer 2009, 100:1277-1286.

23. Pantel $K$, Alix-Panabieres C: Circulating tumour cells in cancer patients: challenges and perspectives. Trends Mol Med 2010, 16:398-406.

24. Uhr JW, Pantel K: Controversies in clinical cancer dormancy. Proc Natl Acad SciUSA 2011, 108:12396-12400 
25. Payne RE, Hava NL, Page K, Blighe K, Ward B, Slade M, Brown J, Guttery DS, Zaidi SA, Stebbing J, Jacob J, Yagüe E, Shaw JA, Coombes RC: The presence of disseminated tumour cells in the bone marrow is inversely related to circulating free DNA in plasma in breast cancer dormancy. Br J Cancer 2012, 106:375-382

26. Umetani N, Giuliano AE, Hiramatsu SH, Amersi F, Nakagawa T, Martino S Hoon DS: Prediction of breast tumor progression by integrity of free circulating DNA in serum. J Clin Oncol 2006, 24:4270-4276.

27. Deligezer U, Eralp Y, Akisik EE, Akisik EZ, Saip P, Topuz E, Dalay N: Size distribution of circulating cell-free DNA in sera of breast cancer patients in the course of adjuvant chemotherapy. Clin Chem Lab Med 2008, 46:311-317.

28. Schwarzenbach H, Muller V, Beeger C, Gottberg M, Stahmann N, Pantel K: A critical evaluation of loss of heterozygosity detected in tumor tissues, blood serum and bone marrow plasma from patients with breast cancer. Breast Cancer Res 2007, 9:R66.

29. Schulte-Hermann R, Bursch W, Grasl-Kraupp B, Torok L, Ellinger A, Mullauer L: Role of active cell death (apoptosis) in multi-stage carcinogenesis. Toxicol Lett 1995, 82-83:143-148.

30. Chen X, Bonnefoi H, Diebold-Berger S, Lyautey J, Lederrey C, Faltin-Traub E, Stroun $M$, Anker P: Detecting tumor-related alterations in plasma or serum DNA of patients diagnosed with breast cancer. Clin Cancer Res 1999, 5:2297-2303.

31. Schwarzenbach H, Pantel K, Kemper B, Beeger C, Otterbach F, Kimmig R, Kasimir-Bauer S: Comparative evaluation of cell-free tumor DNA in blood and disseminated tumor cells in bone marrow of patients with primary breast cancer. Breast Cancer Res 2009, 11:R71.

32. Silva JM, Garcia JM, Dominguez G, Silva J, Miralles C, Cantos B, Coca S, Provencio M, Espana P, Bonilla F: Persistence of tumor DNA in plasma of breast cancer patients after mastectomy. Ann Surg Oncol 2002, 9:71-76.

33. Silva JM, Silva J, Sanchez A, Garcia JM, Dominguez G, Provencio M, Sanfrutos $L$, Jareño E, Colas A, España P, Bonilla F: Tumor DNA in plasma at diagnosis of breast cancer patients is a valuable predictor of disease-free survival. Clin Cancer Res 2002, 8:3761-3766.

34. Schwarzenbach H, Eichelser C, Kropidlowski J, Janni W, Rack B, Pantel K: Loss of heterozygosity at tumor suppressor genes detectable on fractionated circulating cell-free tumor DNA as indicator of breast cancer progression. Clin Cancer Res 2012, 18:5719-5730.

35. Leary RJ, Sausen M, Kinde I, Papadopoulos N, Carpten JD, Craig D, O'Shaughnessy J, Kinzler KW, Parmigiani G, Vogelstein B, Diaz LA Jr., Velculescu VE: Detection of chromosomal alterations in the circulation of cancer patients with whole-genome sequencing. Sci Trans/ Med 2012, 4:162ra154.

36. Murtaza M, Dawson SJ, Tsui DW, Gale D, Forshew T, Piskorz AM, Parkinson C, Chin SF, Kingsbury Z, Wong AS, Marass F, Humphray S, Hadfield J, Bentley D, Chin TM, Brenton JD, Caldas C, Rosenfeld N: Non-invasive analysis of acquired resistance to cancer therapy by sequencing of plasma DNA Nature 2013, 497:108-112.

37. Shao ZM, Wu J, Shen ZZ, Nguyen M: p53 mutation in plasma DNA and its prognostic value in breast cancer patients. Clin Cancer Res 2001, 7:2222-2227.

38. Page K, Hava N, Ward B, Brown J, Guttery DS, Ruangpratheep C, Blighe K, Sharma A, Walker RA, Coombes RC, Shaw JA: Detection of HER2 amplification in circulating free DNA in patients with breast cancer. $\mathrm{Br} J$ Cancer 2011, 104:1342-1348.

39. Board RE, Wardley AM, Dixon JM, Armstrong AC, Howell S, Renshaw L, Donald E, Greystoke A, Ranson M, Hughes A, Dive C: Detection of PIK3CA mutations in circulating free DNA in patients with breast cancer. Breast Cancer Res Treat 2010, 120:461-467.

40. Shaw JA, Page K, Blighe K, Hava N, Guttery D, Ward B, Brown J, Ruangpratheep C, Stebbing J, Payne R, Palmieri C, Cleator S, Walker RA, Coombes RC: Genomic analysis of circulating cell-free DNA infers breast cancer dormancy. Genome Res 2012, 22:220-231.

41. Bechmann T, Andersen RF, Pallisgaard N, Madsen JS, Maae E, Jakobsen EH, Bak Jylling AM, Steffensen KD, Jakobsen A: Plasma HER2 amplification in cell-free DNA during neoadjuvant chemotherapy in breast cancer. J Cancer Res Clin Oncol 2013, 139:995-1003.

42. Kristensen LS, Hansen LL: PCR-based methods for detecting single-locus DNA methylation biomarkers in cancer diagnostics, prognostics, and response to treatment. Clin Chem 2009, 55:1471-1483.

43. Agostini M, Enzo MV, Bedin C, Belardinelli V, Goldin E, Del Bianco P, Maschietto E, D’Angelo E, Izzi L, Saccani A, Zavagno G, Nitti D: Circulating cell-free DNA: a promising marker of regional lymphonode metastasis in breast cancer patients. Cancer Biomark 2012, 11:89-98.

44. Jing F, Zhang J, Tao J, Zhou Y, Jun L, Tang X, Wang Y, Hai H: Hypermethylation of tumor suppressor genes BRCA1, p16 and 14-3-3sigma in serum of sporadic breast cancer patients. Onkologie 2007, 30:14-19.

45. Hesson LB, Cooper WN, Latif F: The role of RASSF1A methylation in cancer. Dis Markers 2007, 23:73-87.

46. Kloten V, Becker B, Winner K, Schrauder MG, Fasching PA, Anzeneder T, Veeck J, Hartmann A, Knuchel R, Dahl E: Promoter hypermethylation of the tumorsuppressor genes ITIH5, DKK3, and RASSF1A as novel biomarkers for blood-based breast cancer screening. Breast Cancer Res 2013, 15:R4.

47. Yazici H, Terry MB, Cho YH, Senie RT, Liao Y, Andrulis I, Santella RM: Aberrant methylation of RASSF1A in plasma DNA before breast cancer diagnosis in the Breast Cancer Family Registry. Cancer Epidemiol Biomarkers Prev 2009, 18:2723-2725

48. Chimonidou M, Tzitzira A, Strati A, Sotiropoulou G, Sfikas C, Malamos N, Georgoulias V, Lianidou E: CST6 promoter methylation in circulating cellfree DNA of breast cancer patients. Clin Biochem 2013, 46:235-240.

49. Turk V, Bode W: The cystatins: protein inhibitors of cysteine proteinases. FEBS Lett 1991, 285:213-219.

50. Van De Voorde L, Speeckaert R, Van Gestel D, Bracke M, De Neve W, Delanghe J, Speeckaert M: DNA methylation-based biomarkers in serum of patients with breast cancer. Mutat Res 2012, 751:304-325.

51. Radpour R, Barekati Z, Kohler C, Lv Q, Burki N, Diesch C, Bitzer J, Zheng H, Schmid S, Zhong XY: Hypermethylation of tumor suppressor genes involved in critical regulatory pathways for developing a blood-based test in breast cancer. PLoS One 2011, 6:e16080.

52. Yamamoto N, Nakayama T, Kajita M, Miyake T, Iwamoto T, Kim SJ, Sakai A, Ishihara $\mathrm{H}$, Tamaki Y, Noguchi S: Detection of aberrant promoter methylation of GSTP1, RASSF1A, and RARbeta2 in serum DNA of patients with breast cancer by a newly established one-step methylation-specific PCR assay. Breast Cancer Res Treat 2012, 132:165-173.

53. Skvortsova TE, Rykova EY, Tamkovich SN, Bryzgunova OE, Starikov AV, Kuznetsova NP, Vlassov VV, Laktionov PP: Cell-free and cell-bound circulating DNA in breast tumours: DNA quantification and analysis of tumourrelated gene methylation. Br J Cancer 2006, 94:1492-1495.

54. Matuschek C, Bölke E, Lammering G, Gerber PA, Peiper M, Budach W, Taskin H, Prisack HB, Schieren G, Orth K, Bojar H: Methylated APC and GSTP1 genes in serum DNA correlate with the presence of circulating blood tumor cells and are associated with a more aggressive and advanced breast cancer disease. Eur J Med Res 2010, 15:277-286.

55. Chimonidou M, Strati A Malamos N, Georgoulias V, Lianidou ES. SOX17 promoter methylation in circulating tumor cells and matched cell-free DNA isolated from plasma of patients with breast cancer. Clin Chem 2012, 59:270-279.

56. Mirza S, Sharma G, Parshad R, Srivastava A, Gupta SD, Ralhan R: Clinical significance of promoter hypermethylation of ERbeta and RARbeta2 in tumor and serum DNA in Indian breast cancer patients. Ann Surg Oncol 2012, 19:3107-3115

57. Muller HM, Widschwendter A, Fiegl H, Ivarsson L, Goebel G, Perkmann E, Marth C, Widschwendter M: DNA methylation in serum of breast cancer patients: an independent prognostic marker. Cancer Res 2003 63:7641-7645.

58. Fujita N, Nakayama T, Yamamoto N, Kim SJ, Shimazu K, Shimomura A, Maruyama N, Morimoto K, Tamaki Y, Noguchi S: Methylated DNA and total DNA in serum detected by one-step methylation-specific $P C R$ is predictive of poor prognosis for breast cancer patients. Oncology 2012, 83:273-282.

59. Gobel G, Auer D, Gaugg I, Schneitter A, Lesche R, Muller-Holzner E, Marth C, Daxenbichler G: Prognostic significance of methylated RASSF1A and PITX2 genes in blood- and bone marrow plasma of breast cancer patients. Breast Cancer Res Treat 2011, 130:109-117.

60. Liggett TE, Melnikov AA, Marks JR, Levenson W: Methylation patterns in cell-free plasma DNA reflect removal of the primary tumor and drug treatment of breast cancer patients. Int J Cancer 2011, 128:492-499.

61. Fiegl H, Millinger S, Mueller-Holzner E, Marth C, Ensinger C, Berger A, Klocker H, Goebel G, Widschwendter M: Circulating tumor-specific DNA: a marker for monitoring efficacy of adjuvant therapy in cancer patients. Cancer Res 2005, 65:1141-1145.

62. Avraham A, Uhlmann R, Shperber A, Birnbaum M, Sandbank J, Sella A, Sukumar S, Evron E: Serum DNA methylation for monitoring response to neoadjuvant chemotherapy in breast cancer patients. Int J Cancer 2012, 
131:E1166-1172

63. Holdenrieder S, Nagel D, Schalhorn A, Heinemann V, Wilkowski R, von Pawel J, Raith H, Feldmann K, Kremer AE, Müller S, Geiger S, Hamann GF, Seidel D, Stieber P: Clinical relevance of circulating nucleosomes in cancer. Ann NY Acad Sci 2008, 1137:180-189.

64. Roth C, Pantel K, Müller V, Rack B, Janni W, Schwarzenbach H: Apoptosisrelated deregulation of proteolytic activities and high serum levels of circulating nucleosomes and DNA in blood correlate with breast cancer progression. BMC Cancer 2010, 11:4.

65. Kuroi K, Tanaka C, Toi M: Clinical significance of plasma nucleosome levels in cancer patients. Int J Oncol 2001, 19:143-148.

66. Holdenrieder S, Stieber P: Clinical use of circulating nucleosomes. Crit Rev Clin Lab Sci 2009, 46:1-24

67. Leszinski G, Gezer U, Siegele B, Stoetzer O, Holdenrieder S: Relevance of histone marks H3K9me3 and H4K20me3 in cancer. Anticancer Res 2012 32:2199-2205.

68. Orozco AF, Lewis DE: Flow cytometric analysis of circulating microparticles in plasma. Cytometry A 2010, 77:502-514.

69. Cocucci E, Racchetti G, Meldolesi J: Shedding microvesicles: artefacts no more. Trends Cell Biol 2009, 19:43-51.

70. O'Driscoll L, Kenny E, Mehta JP, Doolan P, Joyce H, Gammell P, Hill A, O'Daly B, O'Gorman D, Clynes M: Feasibility and relevance of global expression profiling of gene transcripts in serum from breast cancer patients using whole genome microarrays and quantitative RT-PCR. Cancer Genomics Proteomics 2008, 5:94-104.

71. El-Attar NI, Gaefar HA: Plasma mammaglobin messenger RNA in breast cancer patients as an addition to serum tumor. Egypt I Immunol 2007, 14:111-121.

72. García V, García JM, Peña C, Silva J, Domínquez G, Lorenzo Y, Diaz R, Espinosa P, de Sola JG, Cantos B, Bonilla F: Free circulating mRNA in plasma from breast cancer patients and clinical outcome. Cancer Lett 2008, 263:312-320.

73. Fleischhacker M: Biology of circulating mRNA: still more questions than answers? Ann N Y Acad Sci 2006, 1075:40-49.

74. Kosaka N, Iguchi H, Ochiya T: Circulating microRNA in body fluid: a new potential biomarker for cancer diagnosis and prognosis. Cancer Sci 2010, 101:2087-2092

75. Croce CM: Causes and consequences of microRNA dysregulation in cancer. Nat Rev Genet 2009, 10:704-714.

76. Cookson VJ, Bentley MA, Hogan BV, Horgan K, Hayward BE, Hazelwood LD, Hughes TA: Circulating microRNA profiles reflect the presence of breast tumours but not the profiles of microRNAs within the tumours. Cell Oncol (Dordr) 2012, 35:301-308.

77. Mar-Aguilar F, Mendoza-Ramirez JA, Malagon-Santiago I, Espino-Silva PK, Santuario-Facio SK, Ruiz-Flores P, Rodriguez-Padilla C, Resendez-Perez D: Serum circulating microRNA profiling for identification of potential breast cancer biomarkers. Dis Markers 2013, 34:163-169.

78. Ng EK, Li R, Shin VY, Jin HC, Leung CP, Ma ES, Pang R, Chua D, Chu KM, Law WL, Law SY, Poon RT, Kwong A: Circulating microRNAs as specific biomarkers for breast cancer detection. PLOS One 2013, 8:e53141.

79. Sun Y, Wang M, Lin G, Sun S, Li X, Qi J, Li J: Serum microRNA-155 as a potential biomarker to track disease in breast cancer. PLoS One 2012, 7:e47003.

80. Cuk K, Zucknick M, Heil J, Madhavan D, Schott S, Turchinovich A, Arlt D, Rath M, Sohn C, Benner A, Junkermann H, Schneeweiss A, Burwinkel B: Circulating microRNAs in plasma as early detection markers for breast cancer. Int $J$ Cancer 2013, 132:1602-1612.

81. Schrauder MG, Strick R, Schulz-Wendtland R, Strissel PL, Kahmann L, Loehberg CR, Lux MP, Jud SM, Hartmann A, Hein A, Bayer CM, Bani MR, Richter S, Adamietz BR, Wenkel E, Rauh C, Beckmann MW, Fasching PA: Circulating micro-RNAs as potential blood-based markers for early stage breast cancer detection. PLoS One 2012, 7:e29770.

82. Zhao FL, Hu GD, Wang XF, Zhang XH, Zhang YK, Yu ZS: Serum overexpression of microRNA-10b in patients with bone metastatic primary breast cancer. J Int Med Res 2012, 40:859-866.

83. Chen W, Cai F, Zhang B, Barekati Z, Zhong XY: The level of circulating miRNA-10b and miRNA-373 in detecting lymph node metastasis of breast cancer: potential biomarkers. Tumour Biol 2012, 34:455-462.

84. Ma L, Reinhardt F, Pan E, Soutschek J, Bhat B, Marcusson EG, Teruya-Feldstein J, Bell GW, Weinberg RA: Therapeutic silencing of miR-10b inhibits metastasis in a mouse mammary tumor model. Nat Biotechnol 2010, 28:341-347.
85. van Schooneveld E, Wouters MC, Van der Auwera I, Peeters DJ, Wildiers H, Van Dam PA, Vergote I, Vermeulen PB, Dirix LY, Van Laere SJ: Expression profiling of cancerous and normal breast tissues identifies microRNAs that are differentially expressed in serum from patients with (metastatic) breast cancer and healthy volunteers. Breast Cancer Res 2012, 14:R34.

86. Wang B, Zhang Q: The expression and clinical significance of circulating microRNA-21 in serum of five solid tumors. J Cancer Res Clin Oncol 2012, 138:1659-1666.

87. Han M, Liu M, Wang Y, Mo Z, Bi X, Liu Z, Fan Y, Chen X, Wu C: Re-expression of miR-21 contributes to migration and invasion by inducing epithelialmesenchymal transition consistent with cancer stem cell characteristics in MCF-7 cells. Mol Cell Biochem 2012, 363:427-436.

88. Asaga S, Kuo C, Nguyen T, Terpenning M, Giuliano AE, Hoon DS: Direct serum assay for microRNA-21 concentrations in early and advanced breast cancer. Clin Chem 2011, 57:84-91.

89. Si H, Sun X, Chen Y, Cao Y, Chen S, Wang H, Hu C: Circulating microRNA-92a and microRNA-21 as novel minimally invasive biomarkers for primary breast cancer. J Cancer Res Clin Oncol 2013, 139:223-229.

90. Schwarzenbach H, Milde-Langosch K, Steinbach B, Muller V, Pantel K: Diagnostic potential of PTEN-targeting miR-214 in the blood of breast cancer patients. Breast Cancer Res Treat 2012, 134:933-941.

91. Roth C, Rack B, Muller V, Janni W, Pantel K, Schwarzenbach H: Circulating microRNAs as blood-based markers for patients with primary and metastatic breast cancer. Breast Cancer Res 2010, 12:R90

92. Kong W, Yang H, He L, Zhao JJ, Coppola D, Dalton WS, Cheng JQ: MicroRNA-155 is regulated by the transforming growth factor beta/Smad pathway and contributes to epithelial cell plasticity by targeting RhoA. Mol Cell Biol 2008, 28:6773-6784.

93. Liu J, Mao Q, Liu Y, Hao X, Zhang S, Zhang J: Analysis of miR-205 and miR-155 expression in the blood of breast cancer patients. Chin $J$ Cancer Res 2013, 25:46-54

94. Madhavan D, Zucknick M, Wallwiener M, Cuk K, Modugno C, Scharpff M, Schott S, Heil J, Turchinovich A, Yang R, Benner A, Riethdorf S, Trumpp A, Sohn C, Pantel K, Schneeweiss A, Burwinkel B: Circulating miRNAs as surrogate markers for circulating tumor cells and prognostic markers in metastatic breast cancer. Clin Cancer Res 2012, 18:5972-5982.

95. Mattie MD, Benz CC, Bowers J, Sensinger K, Wong L, Scott GK, Fedele V, Ginzinger D, Getts R, Haqq C: Optimized high-throughput microRNA expression profiling provides novel biomarker assessment of clinical prostate and breast cancer biopsies. Mol Cancer 2006, 5:24.

96. Wang H, Tan G, Dong L, Cheng L, Li K, Wang Z, Luo H: Circulating MiR-125b as a marker predicting chemoresistance in breast cancer. PLoS One 2012, 7:e34210.

97. Jung EJ, Santarpia L, Kim J, Esteva FJ, Moretti E, Buzdar AU, Di Leo A, Le XF, Bast RC Jr., Park ST, Pusztai L, Calin GA: Plasma microRNA 210 levels correlate with sensitivity to trastuzumab and tumor presence in breast cancer patients. Cancer 2012, 118:2603-2614

98. Ivan M, Harris AL, Martelli F, Kulshreshtha R: Hypoxia response and microRNAs: no longer two separate worlds. J Cell Mol Med 2008, 12:1426-1431

99. DeClerck K, Elble RC: The role of hypoxia and acidosis in promoting metastasis and resistance to chemotherapy. Front Biosci 2010, 15:213-225.

100. Leidner RS, Li L, Thompson CL: Dampening enthusiasm for circulating microRNA in breast cancer. PLoS One 2013, 8:e57841.

101. Locke I, Kote-Jarai Z, Bancroft E, Bullock S, Jugurnauth S, Osin P, Nerurkar A, Izatt L, Pichert G, Gui GP, Eeles RA: Loss of heterozygosity at the BRCA1 and BRCA2 loci detected in ductal lavage fluid from BRCA gene mutation carriers and controls. Cancer Epidemiol Biomarkers Prev 2006, 15:1399-1402.

102. Bryzgunova OE, Skvortsova TE, Kolesnikova EV, Starikov AV, Rykova EY, Vlassov W, Laktionov PP: Isolation and comparative study of cell-free nucleic acids from human urine. Ann N Y Acad Sci 2006, 1075:334-340.

doi:10.1186/bcr3446

Cite this article as: Schwarzenbach H: Circulating nucleic acids as

biomarkers in breast cancer. Breast Cancer Research 2013, 15:211. 